\title{
Article \\ Visual Quantitation of Copper Ions Based on a Microfluidic Particle Dam Reflecting the Cu(II)-Catalyzed Oxidative Damage of DNA
}

\author{
Chenyu Cui and Ting-Hsuan Chen *
}

check for

updates

Citation: Cui, C.; Chen, T.-H. Visual Quantitation of Copper Ions Based on a Microfluidic Particle Dam

Reflecting the $\mathrm{Cu}(\mathrm{II})$-Catalyzed

Oxidative Damage of DNA. Biosensors 2021, 11, 487. https://doi.org/ 10.3390/bios11120487

Received: 23 October 2021

Accepted: 28 November 2021

Published: 30 November 2021

Publisher's Note: MDPI stays neutra with regard to jurisdictional claims in published maps and institutional affiliations.

Copyright: (c) 2021 by the authors. Licensee MDPI, Basel, Switzerland This article is an open access article distributed under the terms and conditions of the Creative Commons Attribution (CC BY) license (https:// creativecommons.org/licenses/by/ $4.0 /)$.
Department of Biomedical Engineering, City University of Hong Kong, 83 Tat Chee Avenue, Hong Kong, China; chenyucui2-c@my.cityu.edu.hk

* Correspondence: thchen@cityu.edu.hk

Abstract: Due to the use of copper water pipes and the discharge of industrial wastewater, contamination of copper ions in drinking water has become a severe hazard globally. To routinely check water safety on a daily basis, easy-to-use platforms for quantitative analysis of trace amounts of copper ions $\left(\mathrm{Cu}^{2+}\right)$ in drinking water is needed. Here, we report microfluidic particle accumulation integrated with a $\mathrm{Cu}$ (II)-catalyzed Fenton reaction for visual and quantitative copper ion detection. Microparticles (MMPs) and polystyrene microparticles (PMPs) are connected via a single strand DNA, MB155. However, when $\mathrm{Cu}^{2+}$ is present, MB155 is cleaved by hydroxyl free radicals $(\bullet \mathrm{OH})$ produced from $\mathrm{Cu}^{2+} /$ hydrogen peroxide $\left(\mathrm{H}_{2} \mathrm{O}_{2}\right)$ Fenton reactions, causing an increased amount of free PMPs. To visually count them, the particle solution is loaded onto a microfluidic chip where free MMPs and MMPs-MB155-PMPs can be collected by the magnetic separator, while the free PMPs continue flowing until being accumulated at the particle dam. The results showed a good linear relationship between the trapping length of PMP accumulation and the $\mathrm{Cu}^{2+}$ concentration from 0 to $300 \mathrm{nM}$. A limit of detection (LOD) of $70.1 \mathrm{nM}$ was achieved, which is approximately 449 times lower than the $2 \times 10^{3} \mu \mathrm{g} \cdot \mathrm{L}^{-1}(\sim 31.5 \mu \mathrm{M})$ required by the World Health Organization (WHO). Moreover, the results showed high selectivity and good tolerance to $\mathrm{pH}$ and hardness, indicating compatibility for detection in tap water, suggesting a potential platform for the routine monitoring of copper contamination in drinking water.

Keywords: copper ion; Fenton reaction; microfluidics; visual detection

\section{Introduction}

$\mathrm{Cu}^{2+}$ is an essential element participating in many biological systems such as the central nervous system [1], the immune system [2], and the functioning of internal organs such as the heart [3]. However, an excess amount of $\mathrm{Cu}^{2+}$ may burden the organs and lead to illnesses such as liver and kidney dysfunction [4,5] and neurodegenerative diseases such as Alzheimer's and Parkinson's diseases [6,7]. Unfortunately, because of the increased industrialization and urbanization, the metal deposits from manufacturing byproducts accumulate in the soil and sediments of water bodies, which cannot be completely removed by the existing tap water treatment process and could be even worsened after pipeline transportation. Ultimately, excess ions enter the food chain and seriously affect human health. To avoid this, a maximum level of copper in drinking water was set to $2.00 \times 10^{3} \mu \mathrm{g} \cdot \mathrm{L}^{-1}(\sim 31.5 \mu \mathrm{M})$ by the WHO [8], which is used in the routine analysis and monitoring of trace amounts of $\mathrm{Cu}^{2+}$ in drinking water to ensure water safety.

The traditional detection of $\mathrm{Cu}^{2+}$ relies on atomic absorption spectroscopy (AAS) [9-11], inductively coupled plasma mass spectroscopy (ICP-MS) [12], and high-performance liquid chromatography (HPLC) [13], where bulky equipment, complicated sample preparation, and long testing times are inevitable. To simplify the process, many analytical methods have been developed based on colorimetry [14-16], electrochemistry [17,18], and fluores- 
cence $[19,20]$. Among them, some researchers have achieved $\mathrm{Cu}^{2+}$ detection based on the oxidation-reduction property of $\mathrm{Cu}^{2+}$, which can produce hydroxyl radicals [21,22]. Zhao et al. [23] used silicon quantum dots (SiQDs) with fluorescence for the detection of $\mathrm{Cu}^{2+}$. When $\mathrm{Cu}^{2+}$ is present, the fluorescence is quenched by hydroxyl radicals generating from the Fenton reaction between $\mathrm{H}_{2} \mathrm{O}_{2}$ and $\mathrm{Cu}^{+}$, resulting in a decrease in the fluorescence intensity. However, such a method relies on the fluorescence spectrophotometer, which is still laboratory-based and not user-friendly. In contrast, Wang et al. [24] developed a lateral flow test strip for $\mathrm{Cu}^{2+}$ detection based on $\mathrm{Cu}^{+}$-catalyzed click chemistry and hybridization of single-stranded DNA, where the presence of $\mathrm{Cu}^{2+}$ can be visualized by hybridization of ssDNA-labeled gold nanoparticles. However, lateral flow strips can hardly achieve quantitative measurement and mostly yield only yes/no results.

In this work, we report a visual and quantitative method for detecting $\mathrm{Cu}^{2+}$ on a microfluidic platform (Figure 1). $\mathrm{Cu}^{2+}$, the analyte, is first reduced to $\mathrm{Cu}^{+}$by $\mathrm{H}_{2} \mathrm{O}_{2}$, and the produced $\mathrm{Cu}^{+}$subsequently reacts with $\mathrm{H}_{2} \mathrm{O}_{2}$ using the Fenton reaction, generating $\bullet \mathrm{OH}$ that randomly fragmentizes single-strand DNA oligonucleotides through oxidative damage. Next, $\mathrm{Cu}^{+}$is oxidized to $\mathrm{Cu}^{2+}$, forming a reaction cycle that allows signal amplification. To visualize the DNA damage, MB155, a single-strand DNA, is used to connect MMPs and PMPs through DNA hybridization, forming a sandwich structure, MMPs-MB155-PMPs. In contrast, with the presence of $\mathrm{Cu}^{2+}$, the cleavage of MB155 induced by $\bullet \mathrm{OH}$ leads to separation of MMPs and PMPs. To visualize the altered particle connection, the particle solution is loaded onto a microfluidic chip containing a magnetic separator to remove the free MMPs and MMPs-MB155-PMPs, leaving the PMPs to continue flowing until being trapped and stacked at the trapping channel. As a result, the trapping length of PMP accumulation, which is similar to a thermometer-like display and proportional to the concentration of $\mathrm{Cu}^{2+}$, can be easily read and interpreted by the naked eye. After obtaining the LOD and exploring the selectivity and tolerance to environmental interferences, it was applied to detect $\mathrm{Cu}^{2+}$ in tap water, demonstrating the potential for monitoring $\mathrm{Cu}^{2+}$ contamination in daily drinking water.
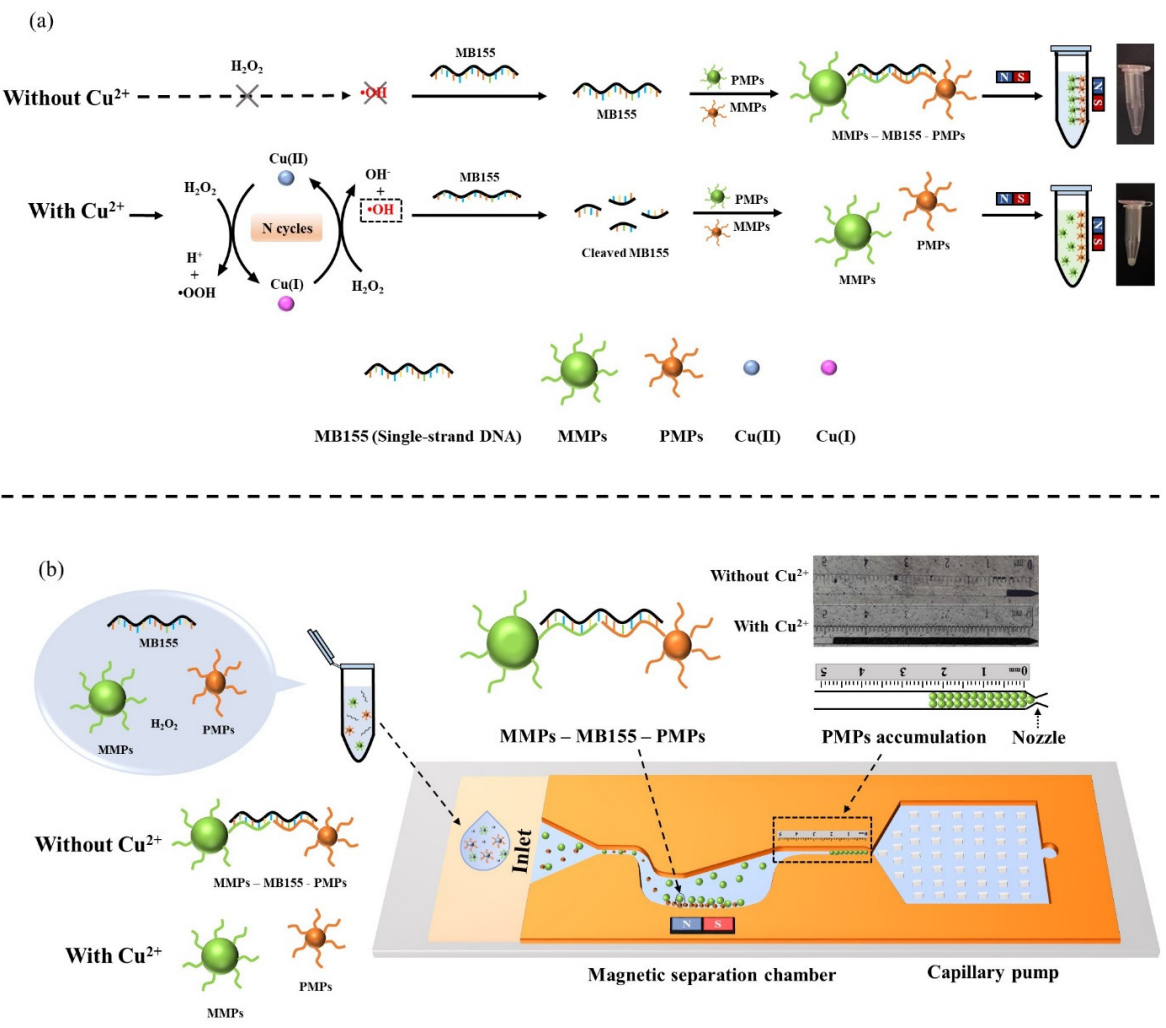

Figure 1. Working principle of the visual quantitative detection of $\mathrm{Cu}^{2+}$. (a) MB155 connects MMPs and PMPs through DNA hybridization, resulting in a clear solution after magnetic separation. In contrast, 
the presence of $\mathrm{Cu}^{2+}$ in $\mathrm{H}_{2} \mathrm{O}_{2}$ generates $\bullet \mathrm{OH}$, which cleaves MB155. As such, microparticles are disconnected, making the solution turbid. (b) After reaction, the particle solution is loaded onto a microfluidic chip, where free MMPs and MMPs-MB155-PMPs are separated by a magnet, and the free PMPs continue flowing until being trapped and accumulated at the particle dam, which is narrow in width, enabling the quantitative determination of $\mathrm{Cu}^{2+}$ by visual inspection.

\section{Materials and Methods}

\subsection{Preparation of Oligonucleotides}

The sequences of P1, P2, and MB155 (BGI BIO-Solutions HONGKONG Co., Ltd., Hong Kong, China) used in this work are shown in Table S1. P1 and P2 were designed with sequences complementary to that of MB155 in juxtaposition. Both P1 and P2 with biotin modification for binding to streptavidin-modified microparticles were purified using high-performance liquid chromatography, while MB155 was purified by polyacrylamide gel electrophoresis. The powdered oligonucleotides received from the suppliers were dissolved in nuclease-free water (Thermo Fisher Scientific, Waltham, MA, USA) to obtain a stock solution of $100 \mu \mathrm{M}$ and stored at $4{ }^{\circ} \mathrm{C}$ for further use.

\subsection{Cu(II)-Catalyzed Fenton Reaction}

For $\mathrm{Cu}^{2+}$ detection, $2 \mu \mathrm{L}$ of MB155 (5 $\mu \mathrm{M}$ for magnetophoresis assay or $3.75 \mu \mathrm{M}$ for microfluidic chip) and $2 \mu \mathrm{L}$ of $5 \mathrm{M}$ of $\mathrm{H}_{2} \mathrm{O}_{2}$ (Anaqua) were mixed with $20 \mu \mathrm{L}$ of $50 \mathrm{mM}$ Tris$\mathrm{HCl}$ buffer ( $\mathrm{pH}=7.4$ ). Next, $76 \mu \mathrm{L}$ of different concentrations of $\mathrm{Cu}^{2+}$ diluted in DI water was added and reacted for $30 \mathrm{~min}$ at room temperature. For the selectivity experiment, the $76 \mu \mathrm{L} \mathrm{Cu}{ }^{2+}$ solution was replaced by different metal ions-cadmium $\left(\mathrm{Cd}^{2+}\right)$, Barium $\left(\mathrm{Ba}^{2+}\right)$, mercury $\left(\mathrm{Hg}^{2+}\right)$, zinc $\left(\mathrm{Zn}^{2+}\right)$, manganese $\left(\mathrm{Mn}^{2+}\right)$, strontium $\left(\mathrm{Sr}^{2+}\right)$, lead $\left(\mathrm{Pb}^{2+}\right)$, and iron $\left(\mathrm{Fe}^{2+}\right)$ (J\&K Scientific, Hong Kong). For testing the $\mathrm{pH}, \mathrm{Cu}^{2+}$ of different $\mathrm{pH}$ values (6.0, $6.5,7.0,7.5$, and 8 ) were prepared by adding $\mathrm{HCl}$ or $\mathrm{NaOH}$. For testing the water hardness, various brands of bottled water with different water hardnesses were used for diluting $\mathrm{Cu}^{2+}$. Here, soft water (Bourbon ${ }^{\mathrm{TM}}$ ) with a hardness of $55.0 \mathrm{mg} / \mathrm{L}$, moderately hard water $\left(\mathrm{FIJI}^{\mathrm{TM}}\right)$ with a hardness of $108 \mathrm{mg} / \mathrm{L}$, hard water $\left(\mathrm{AQUA}^{\mathrm{TM}}\right)$ with a hardness of $158 \mathrm{mg} / \mathrm{L}$, and very hard water $\left(\right.$ Vuttel $\left.^{\mathrm{TM}}\right)$ with a hardness of $318 \mathrm{mg} / \mathrm{L}$ were chosen. For detection in tap water, $76 \mu \mathrm{L}$ of tap water was used.

\subsection{Agarose Gel Electrophoresis}

Five grams of agarose powder (Thermo Fisher Scientific, Waltham, MA, USA) was mixed with $10 \mathrm{~mL}$ of $10 \times$ Tris-Acetate-EDTA (TAE) buffer (Thermo Fisher Scientific, Waltham, MA, USA) and $90 \mathrm{~mL}$ of deionized (DI) water (Milli-Q Plus system, with a resistivity of $18.2 \mathrm{M} \Omega \mathrm{cm}$ ), followed by heating in a microwave for $2 \mathrm{~min}$ to fully dissolve the agarose. Next, $3 \mu \mathrm{L}$ of 10,000 $\times$ GelRed $^{\circledR}$ Nucleic Acid Gel Stain (Biotium, Fremont, CA, USA) was added, followed by heating for another $1 \mathrm{~min}$. Then, the dissolved agarose was poured into a tray with a well comb in place immediately. After cooling down for $30 \mathrm{~min}$, the solidified gel was placed into the gel box and covered by $1 \times$ TAE buffer. An ultra-low range DNA ladder (SM1211, Thermo Fisher Scientific, Waltham, MA, USA) was 5 times diluted and then loaded into the first lane of the gel. Then, $10 \mu \mathrm{L}$ of the reaction mixture containing $2 \mu \mathrm{L}$ of $5 \mu \mathrm{M}$ MB155, $2 \mu \mathrm{L}$ of $5 \mathrm{mM} \mathrm{H}_{2} \mathrm{O}_{2}, 2 \mu \mathrm{L}$ of $5 \mathrm{mM} \mathrm{Cu}^{2+}, 2 \mu \mathrm{L}$ of $50 \mathrm{mM}$ Tris- $\mathrm{HCl}$ buffer, and $2 \mu \mathrm{L}$ of DI water was mixed with $2 \mu \mathrm{L}$ of $6 \times$ DNA loading dye (Thermo Fisher Scientific, Waltham, MA, USA) and loaded into the additional wells of the gel. After running at $120 \mathrm{~V}$ for $60 \mathrm{~min}$, a gel image was obtained using a BIO-RAD Gel Doc EZ Imager.

\subsection{Magnetophoresis Assay}

First, $3.5 \mu \mathrm{L}$ of MMPs (CME0101, $0.86 \mu \mathrm{m}$ in diameter, streptavidin-coated, $1.827 \times 10^{10}$ microspheres/mL, Bangs Laboratories, Inc., Fishers, IN, USA) was mixed with $3.5 \mu \mathrm{L}$ of biotin-modified P1, while $2.5 \mu \mathrm{L}$ of PMPs (CFDG004, $0.955 \mu \mathrm{m}$ in diameter, 
streptavidin-coated, $2.07 \times 10^{10}$ microspheres $/ \mathrm{mL}$, Bangs Laboratories, Inc., Fishers, IN, USA) were mixed with $2.5 \mu \mathrm{L}$ of biotin-modified P2. The mixture was shaken at room temperature for 30 min to obtain MMPs-P1 and PMPs-P2 complexes through streptavidinbiotin bonds. Then, the excess probe was removed by rinsing with washing buffer ( $50 \mathrm{mM}$ Tris- $\mathrm{HCl}, 150 \mathrm{mM} \mathrm{NaCl}, \mathrm{pH}=7.4,0.2 \%$ Tween 20, $\mathrm{pH} 7.5)$ three times. During this step, a magnetic rack was applied for 1 min to collect MMPs, while for the separation of PMPs, a centrifuge at $13.3 \times g$ was conducted for $2 \mathrm{~min}$. After washing, the particle solution was brought back to its original volume. Then, $10 \mu \mathrm{L}$ of the resulting solution from the $\mathrm{Cu}^{2+}$-induced Fenton reaction was extracted and added to a mixture of $3.5 \mu \mathrm{L}$ of MMPs-P1, $2.5 \mu \mathrm{L}$ of PMPs-P2, and $4 \mu \mathrm{L}$ of washing buffer, followed by 30 min of shaking for the formation of MMPs-MB155-PMPs. After placing the solution on a magnetic rack to collect the separated MMPs and the complex of MMPs-MB155-PMPs, the turbidity of supernatant was observed by the naked eye, or measured by the optical absorbance at $365 \mathrm{~nm}$ by UV-Vis spectrometer (BioDrop $\mu$ LITE, Cambridge, UK).

\subsection{Detection on the Microfluidic Chip}

The fabrication process of the chip is shown in the Supplementary Materials. For detection on the chip, MMPs $(0.32 \mu \mathrm{m}$ diameter, SVM- $025-5 \mathrm{H}$, streptavidin-coated, $5 \mathrm{mg} / \mathrm{mL}$, Spherotech. Inc., Lake Forest, IL, USA) were washed three times by MES buffer (100 mM MES, $0.1 \%$ BSA, 0.1\% Tween 20, pH 4.5) and incubated in MES buffer for $1 \mathrm{~h}$ with the original volume. After that, $5 \mu \mathrm{L}$ of MMPs was mixed with $5 \mu \mathrm{L}$ of $100 \mu \mathrm{M}$ P1, while $5 \mu \mathrm{L}$ of PMPs (15.3 $\mu \mathrm{m}$ diameter, CP01008, streptavidin-coated, $5.033 \times 10^{6}$ microspheres $\mathrm{mL}^{-1}$, Bangs Laboratories, Inc., Fishers, IN, USA) was mixed with $5 \mu \mathrm{L}$ of $100 \mu \mathrm{M}$ P2, followed by shaking for $30 \mathrm{~min}$. The same washing steps as that for the magnetophoresis assay were used, as follows. Before loading to the chip, $5 \mu \mathrm{L}$ of the resulting solution after the $\mathrm{Cu}^{2+}$-induced Fenton reaction, as mentioned, was extracted and mixed with $5 \mu \mathrm{L}$ of MMPs-P1 and $5 \mu \mathrm{L}$ of PMPs-P2 with gentle shaking for $30 \mathrm{~min}$. Finally, $3 \mu \mathrm{L}$ of the final solution was loaded at the microfluidic chip's inlet and flowed into the channel based on capillary force. The free MMPs and MMPs-MB155-PMPs were attracted to the bottom of the magnetic separator of the chip, while the non-connected PMPs with a diameter of $15.3 \mu \mathrm{m}$ were blocked at the trapping channel with an $8 \mu \mathrm{m}$ wide particle dam. The trapping length after PMP accumulation was inspected by the naked eye and recorded by a microscope.

\section{Results and Discussion}

\subsection{Agarose Gel Electrophoresis of the Cleaved ssDNA}

Agarose gel was used to identify the base damage of $\mathrm{MB} 155$ by $\mathrm{H}_{2} \mathrm{O}_{2}$ in the presence of $\mathrm{Cu}^{2+}$ (Figure 2). As shown in Lanes 2 and $3, \mathrm{H}_{2} \mathrm{O}_{2}$ or $\mathrm{Cu}^{2+}$ alone did not cause noticeable cleavage of MB155, but the band of MB155 disappeared when $\mathrm{Cu}^{2+}$ and $\mathrm{H}_{2} \mathrm{O}_{2}$ coexisted (Lane 4), which demonstrates the efficient cleavage of MB155 induced by $\bullet \mathrm{OH}$ generated from $\mathrm{H}_{2} \mathrm{O}_{2}$ and $\mathrm{Cu}^{2+}$.

\subsection{Magnetophoresis Assay}

The magnetophoresis assay was first used to assess the altered connection between MMPs and PMPs upon the cleavage of MB155 induced by the $\mathrm{Cu}^{2+} / \mathrm{H}_{2} \mathrm{O}_{2}$ system. The MMPsMB155-PMPs complex was formed due to the hybridization of MB155 with P1 and P2 modified on microparticles. When applying a magnetic force, MMPs and MMPs-MB155-PMPs were pulled onto the tube wall, leaving non-connected PMPs suspending in the solution (Figure 1). Thus, when there was no $\mathrm{Cu}^{2+}$, almost all of the PMPs were in the form of MMPs-MB155-PMPs, which could be separated from the solution after magnetic attraction, resulting in a clear solution. On the contrary, adding $\mathrm{Cu}^{2+}$ would make the solution turbid due to the Mie scattering from increased free PMPs, which could be measured by the relative optical absorbance at $365 \mathrm{~nm}$ of the supernatant with PMPs. 


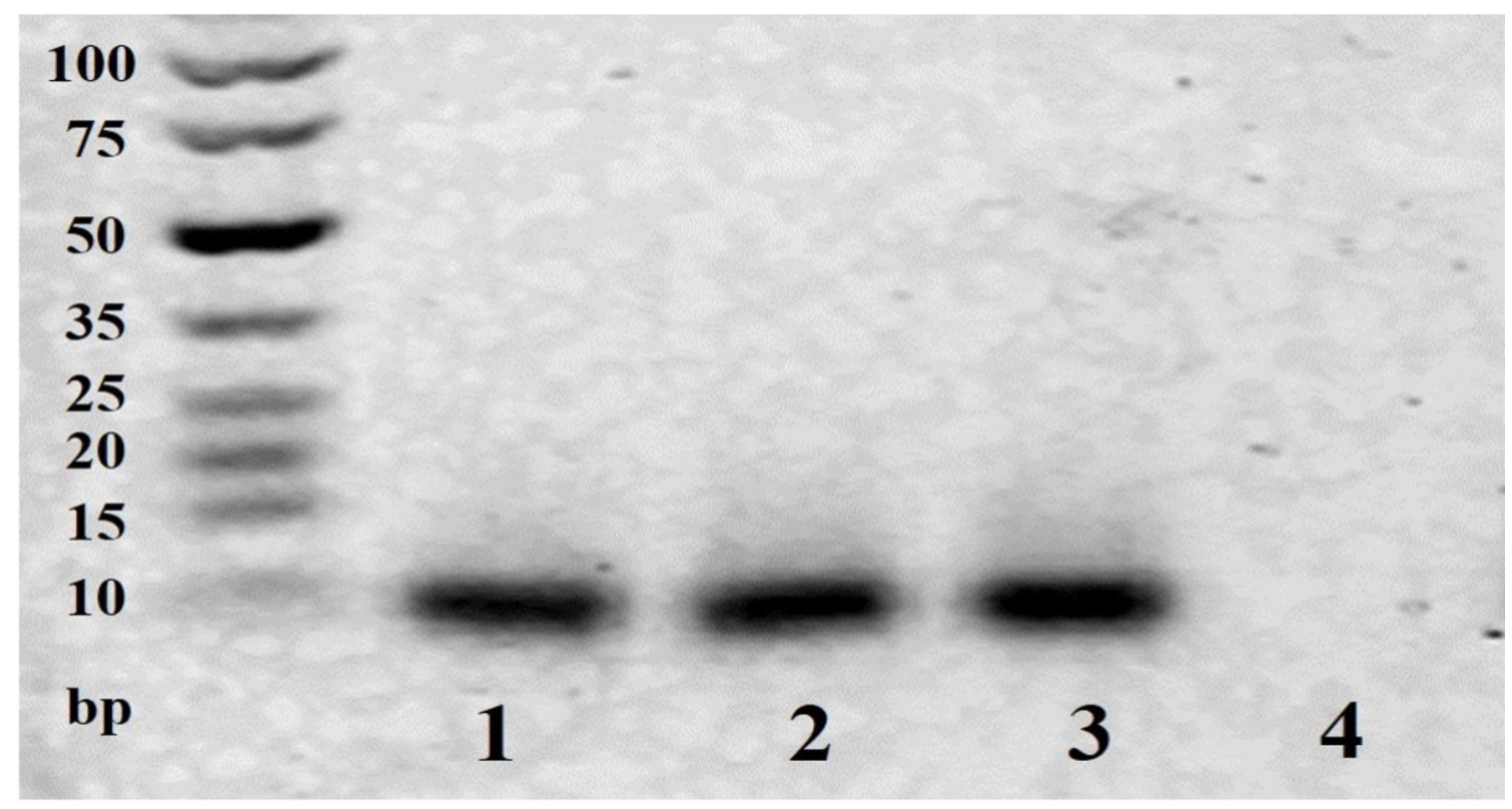

Figure 2. Agarose gel of MB155 cleavage. (Lane 1: MB155; Lane 2: $\mathrm{MB155}+\mathrm{H}_{2} \mathrm{O}_{2}$; Lane 3: $\mathrm{MB} 155+\mathrm{Cu}^{2+}$; $\mathrm{Lane}_{4}$ : $\left.\mathrm{MB} 155+\mathrm{H}_{2} \mathrm{O}_{2}+\mathrm{Cu}^{2+}\right)$. Concentration $(\mathrm{MB} 155)=1 \mu \mathrm{M}$. Concentration $\left(\mathrm{H}_{2} \mathrm{O}_{2}\right.$ and $\left.\mathrm{Cu}^{2+}\right)=1 \mathrm{mM}$.

With a magnetophoresis assay to quantify the particle connection, different concentrations of MB155 and $\mathrm{H}_{2} \mathrm{O}_{2}$ and reaction times were optimized (Figure S1). First, $50 \mathrm{nM}$ of MB155 (in the final solution containing $\mathrm{Cu}^{2+}, \mathrm{H}_{2} \mathrm{O}_{2}$, MMPs, and PMPs) was chosen as the optimal concentration because of its highest signal-to-noise ratio (Figure S1a). For optimization of the $\mathrm{H}_{2} \mathrm{O}_{2}$ concentration, $10 \mathrm{mM}$ of $\mathrm{H}_{2} \mathrm{O}_{2}$ was inadequate for reacting with trace amounts of $\mathrm{Cu}^{2+}$. However, $1000 \mathrm{mM}$ of $\mathrm{H}_{2} \mathrm{O}_{2}$ may cause undesired damage to particle connections, as seen by the high absorbance value of the blank control. Therefore, $100 \mathrm{mM}$ of $\mathrm{H}_{2} \mathrm{O}_{2}$ was selected (Figure S1b). The reaction time for $\mathrm{Cu}^{2+}$ and $\mathrm{H}_{2} \mathrm{O}_{2}$ was also optimized as $30 \mathrm{~min}$, as it achieved the ideal low background and was still sufficient to generate $\bullet \mathrm{OH}$ to cleave the MB155 (Figure S1c).

After optimizing the experimental conditions, we explored the limit of detection under a series of $\mathrm{Cu}^{2+}$ concentrations $(0 \mathrm{nM}, 5 \mathrm{nM}, 10 \mathrm{nM}, 50 \mathrm{nM}, 100 \mathrm{nM}, 200 \mathrm{nM}, 300 \mathrm{nM}, 400 \mathrm{nM}$, $500 \mathrm{nM}$, and $1000 \mathrm{nM}$ ). The turbidity of the extracted suspension after magnetic separation became opaquer with the increment in the $\mathrm{Cu}^{2+}$ concentration (Figure 3a). In addition, the difference could be visually distinguished when the $\mathrm{Cu}^{2+}$ concentration reached $50 \mathrm{nM}$. To obtain more accurate quantification, a UV-Vis spectrometer was applied to measure the optic absorbance spectrum corresponding to the Mie scattering effect caused by free PMPs (Figure $3 \mathrm{~b}$ ). The results showed an increment in the absorbance value accompanying the increase in the $\mathrm{Cu}^{2+}$ concentration. Moreover, there was a significant linear relationship between the $\mathrm{Cu}^{2+}$ concentration and absorbance within the range of $0-200 \mathrm{nM}$. The linear regression equation was $y=0.000975 x+0.176 \pm 0.0301\left[\frac{7}{18}+\frac{(x-60.8)^{2}}{6.82 \times 10^{5}}\right]^{\frac{1}{2}}\left(R^{2}=0.985\right)$, where $x$ represents the concentration of $\mathrm{Cu}^{2+}$ and $y$ means the absorbance value. The value of $S_{\mathrm{b} 1}$ (the uncertainty of the slope) and $S_{\mathrm{b} 0}$ (the uncertainty of the intercept) were $6.07 \times 10^{-5}$ and 0.00568 , respectively (Figure $3 \mathrm{~d}$ ). Thus, the LOD was $67.8 \mathrm{nM}$ (see detailed calculation equations in the Supplementary Materials) $[25,26]$. 
(a)

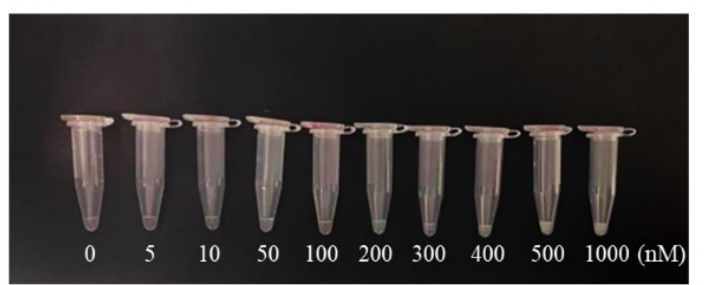

(c)

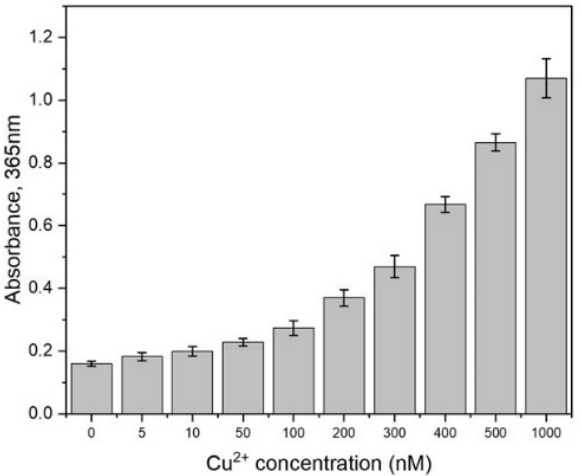

(b)

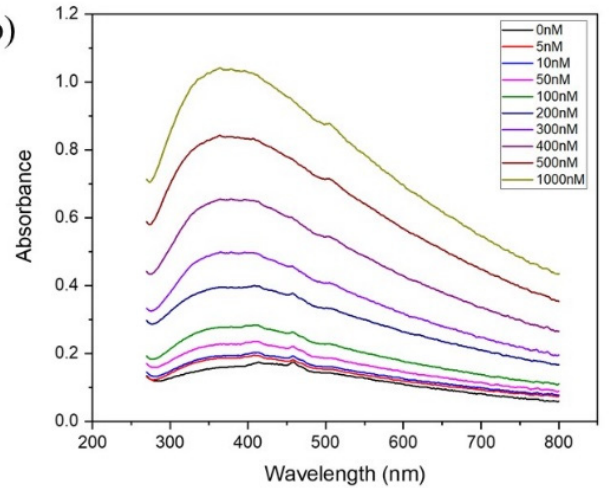

(d)

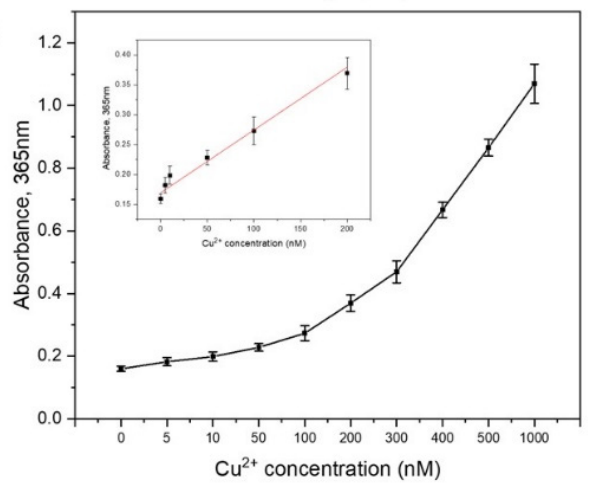

Figure 3. Magnetophoresis assay for $\mathrm{Cu}^{2+}$ detection. (a) Optical image showing the change in the turbidity of the solution from clear to turbid with the increasing concentration of $\mathrm{Cu}^{2+}$. (b) Absorbance spectrum of solutions under different concentrations of $\mathrm{Cu}^{2+}$. (c) Absorbance value (mean \pm maximum deviation, $n=3$ ) at $365 \mathrm{~nm}$ corresponding to (a). (d) Linear regression of the absorbance value versus $\mathrm{Cu}^{2+}$ concentration.

\subsection{LOD on the Microfluidic Chip Test}

Next, considering the application for routine checking on a daily basis, we applied the microfluidic chip for visual and quantitative detection of $\mathrm{Cu}^{2+}$, such that the use of a UV-Vis spectrometer could be avoided. The $\mathrm{H}_{2} \mathrm{O}_{2}$ concentration and reaction time were based on the optimized results of the magnetophoresis assay. Here, because magnetic separation was carried out during capillary-driven particle flowing, smaller MMPs $(0.32 \mu \mathrm{m}$ in diameter) were used to minimize the drag force during magnetic separation. Additionally, the diameter of the PMPs was also changed to $15.3 \mu \mathrm{m}$, such that the particle dam with an $8 \mu \mathrm{m}$ width could block the PMPs. Thus, the particle ratio and the MB155 concentration for optimal particle connection were further explored. At first, we used a 1:1 volume ratio of MMPs and PMPs to optimize the MB155 concentration to be $125 \mathrm{nM}$ based on its shortest trapping length of PMP accumulation (Figure S2a). Next, the amount of MMPs was diluted while maintaining the same ratio of MMPs to MB155. The results showed that a $5 \times$ dilution of MMPs with $25 \mathrm{nM}$ of MB155 was sufficient to connect the PMPs (Figure S2b).

Next, the LOD was obtained by recording the trapping length with a varied concentration of $\mathrm{Cu}^{2+}$. The results showed an increasing trapping length when the $\mathrm{Cu}^{2+}$ concentration increased, which achieved visual quantitation of $\mathrm{Cu}^{2+}$ (Figure 4). Notably, the linear range was from 0 to $300 \mathrm{nM} \mathrm{Cu}^{2+}$ (Figure 3c), which could be fitted with linear regression Equation (1),

$$
\begin{aligned}
& y=0.020 \mathrm{x}+0.938 \pm 0.597\left[\frac{4}{9}+\frac{(\mathrm{x}-50.0)^{2}}{7.26 \times 10^{4}}\right]^{\frac{1}{2}},\left(\mathrm{R}^{2}=0.996, S_{b 1}=0.00135, \text { and } S_{b 0}=0.0870\right) \\
& \text { for } 0-100 \mathrm{nM} \text { of } \mathrm{Cu}^{2+} \text { and Equation }(2), \\
& y=0.00883 \mathrm{x}+2.04 \pm 0.0236\left[\frac{4}{9}+\frac{(\mathrm{x}-200)^{2}}{2.18 \times 10^{5}}\right]^{\frac{1}{2}},\left(\mathrm{R}^{2}=0.999, S_{b 1}=9.62 \times 10^{-5}, \text { and } S_{b 0}=0.0208\right)
\end{aligned}
$$


for 100-300 $\mathrm{nM}$ of $\mathrm{Cu}^{2+}$, where $y$ represents the trapping length and $x$ represents the concentration of $\mathrm{Cu}^{2+}$. Thus, the LOD could be determined as $70.1 \mathrm{nM}$ according to Equation (1) (see detailed calculation equations from the Supplementary Materials) [25,26]. Considering the prescribed toxicity standard, i.e., $\sim 30 \mu \mathrm{M}$ in Hong Kong, $\sim 20 \mu \mathrm{M}$ from the US EPA (United States Environmental Protection Agency), and 15 $\mu \mathrm{M}$ in mainland China, such an LOD was sufficiently low to monitor the toxicity level of the copper contamination in drinking water and comparable to other reported methods while achieving visual quantification (Table 1).

(a)

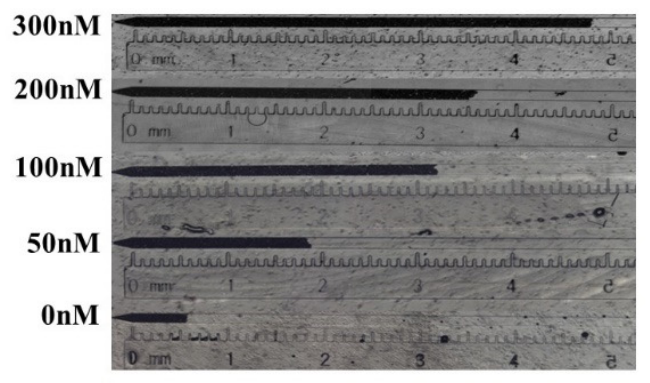

(b)

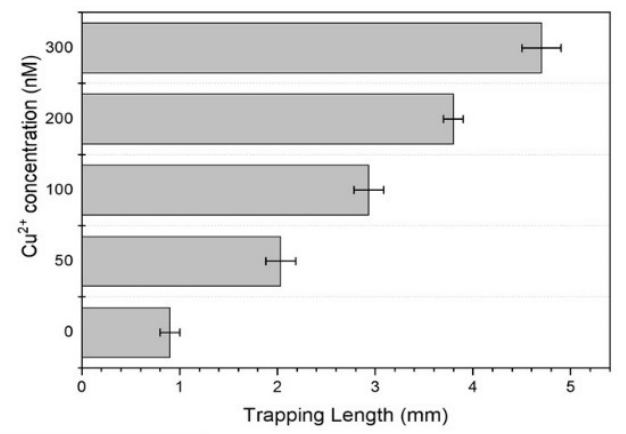

(c)

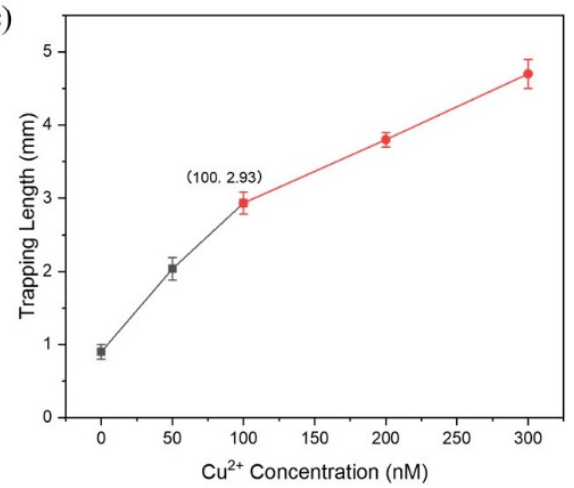

Figure 4. $\mathrm{Cu}^{2+}$ detection on the microfluidic chip. (a) Optical image showing the accumulating PMPs under different $\mathrm{Cu}^{2+}$ concentrations. (b) The trapping length (mean \pm maximum deviation, $n=3$ ) corresponding to (a). (c) The linear relationship between the trapping length and the $\mathrm{Cu}^{2+}$ concentration.

Table 1. The comparison between this work and recently reported $\mathrm{Cu}^{2+}$ detection works.

\begin{tabular}{|c|c|c|c|c|}
\hline Method & LOD & Linear Range & Quantification & Ref. \\
\hline Fluorescence & $0.15 \mu \mathrm{M}$ & $0.1-0.6 \mu \mathrm{M}$ & Fluorescence spectra & [19] \\
\hline Colorimetric & $23 \mathrm{nM}$ & $0.1-10 \mu \mathrm{M}$ & Absorption spectra & [21] \\
\hline Fluorescence & $115 \mathrm{nM}$ & $0.333-66.6 \mu \mathrm{M}$ & Fluorescence spectra & [27] \\
\hline Visualization & $70.1 \mathrm{nM}$ & 0-300 nM & The naked eye & This work \\
\hline
\end{tabular}

\subsection{Tolerance to Environmental Interference}

The tolerance to other interferences was investigated to verify its compatibility with drinking water. We conducted the test under different common metal ions such as $\mathrm{Cd}^{2+}$, $\mathrm{Ba}^{2+}, \mathrm{Hg}^{2+}, \mathrm{Zn}^{2+} \mathrm{Mn}^{2+}, \mathrm{Sr}^{2+}, \mathrm{Pb}^{2+}$, and $\mathrm{Fe}^{2+}$. As shown in Figure 5a, all of the metal ions with high concentrations $(10 \mu \mathrm{M})$, except for $\mathrm{Fe}^{2+}$, hardly caused a significant increase in the trapping length. In contrast, $\mathrm{Fe}^{2+}$ was able to react with $\mathrm{H}_{2} \mathrm{O}_{2}$ and generate $\bullet \mathrm{OH}$ based on the Fenton reaction. However, $200 \mathrm{nM}$ of $\mathrm{Fe}^{2+}$ caused a slight increase in the trapping length, i.e., $1.7 \mathrm{~mm}$, but the presence of $100 \mathrm{nM}$ of $\mathrm{Cu}^{2+}$ led to a much longer accumulation of PMPs, i.e., $3.2 \mathrm{~mm}$, suggesting a more active and stable generation of $\bullet \mathrm{OH}$ by the $\mathrm{Cu}^{2+} / \mathrm{H}_{2} \mathrm{O}_{2}$ system [28]. Next, we tested the tolerance to water hardness by collecting water samples with different hardnesses. For detection of $100 \mathrm{nM}$ copper 
ions, the trapping lengths were significantly longer than that of the blank control, which demonstrates a high stability of $\mathrm{Cu}^{2+}$ sensing in various water hardnesses (Figure $5 b$ ). For detecting $\mathrm{Cu}^{2+}$ in an acidic/basic medium, $\mathrm{Cu}^{2+}$ was added to water with a $\mathrm{pH}$ value from 6.0 to 8.0. The results showed that there was an obvious contrast in the trapping length between the sample with and without $\mathrm{Cu}^{2+}$, demonstrating a high tolerance to acidic or basic water environments (Figure 5 c).

(a)

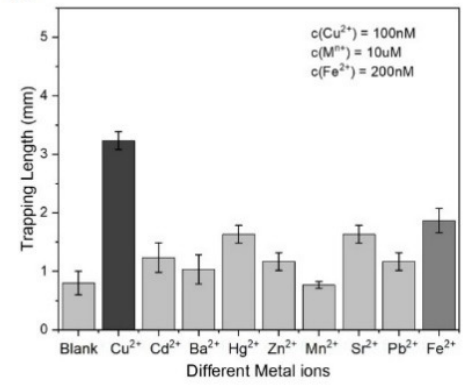

(b)

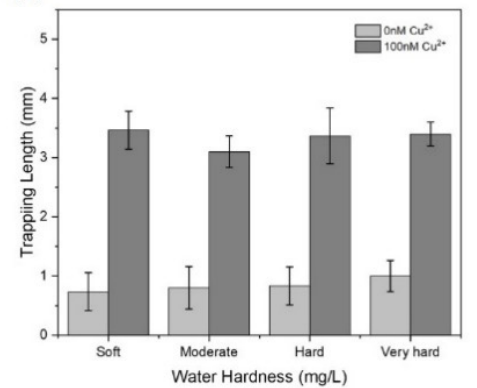

(c)

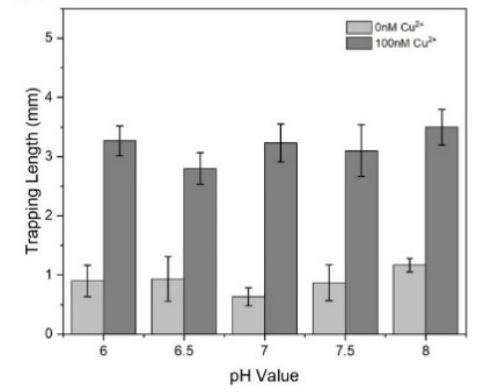

Figure 5. Tolerance of the proposed detection method to environmental interferences. (a) Selectivity in the presence of other metal ions $\left(\mathrm{Cd}^{2+}, \mathrm{Ba}^{2+}, \mathrm{Hg}^{2+}, \mathrm{Zn}^{2+} \mathrm{Mn}^{2+}, \mathrm{Sr}^{2+}, \mathrm{Pb}^{2+}\right.$, and $\left.\mathrm{Fe}^{2+}\right)$ with higher concentrations. (b). Detection of $\mathrm{Cu}^{2+}$ in environments with different water hardnesses (soft: $55.0 \mathrm{mg} / \mathrm{L}$; moderately hard: $108 \mathrm{mg} / \mathrm{L}$; hard: $158 \mathrm{mg} / \mathrm{L}$; very hard: $318 \mathrm{mg} / \mathrm{L}$ ). (c) Detection of $\mathrm{Cu}^{2+}$ in a $\mathrm{pH}$ range from 6.0 to 8.0 (mean \pm maximumf deviation, $n=3$ ).

\subsection{Detection of $\mathrm{Cu}^{2+}$ in Tap Water}

Based on the high sensitivity and good environmental tolerance, we next applied the detection to a tap water sample as a practical application. Tap water is a common source of $\mathrm{Cu}^{2+}$ contamination in daily life because of the use of copper in water pipes, which may cause damage to health. We applied our detection method to measure the $\mathrm{Cu}^{2+}$ concentration in tap water. The tap water sample contained $393 \mathrm{nM}$ of $\mathrm{Cu}^{2+}$, determined by ICP-MS. Remarkably, the trapping length was $3.5 \pm 0.15 \mathrm{~mm}$ for detecting copper ions in a $2 \times$ diluted tap water sample with a total $65 \mathrm{~min}$ assay response time, which was calculated as $165 \pm 5.46 \mathrm{nM}$ using the inverse regression of Equation (2). After multiplying the dilution factor, the concentration of $\mathrm{Cu}^{2+}$ in the tap water was determined as $330 \pm 10.9 \mathrm{nM}$, suggesting an $84.0 \%$ accuracy rate for application to tap water.

\section{Conclusions}

This work presented an enzyme-free, convenient, and effective strategy for visualizing and quantifying $\mathrm{Cu}^{2+}$ based on single-strand DNA cleavage in the $\mathrm{Cu}^{2+} / \mathrm{H}_{2} \mathrm{O}_{2}$ system and the accumulation of PMPs as a thermometer-like display readable by the naked eye. The design showed excellent sensitivity with an LOD of $70.1 \mathrm{nM}$, which is much lower than the maximum contaminant level, i.e., $31.5 \mu \mathrm{M}$, in drinking water according to the WHO. In addition, the method demonstrated a high selectivity and good tolerance to water hardness and $\mathrm{pH}$. More importantly, it can be applied to detect $\mathrm{Cu}^{2+}$ in actual tap water samples with high accuracy $(84.0 \%)$, demonstrating its potential for controlling copper contamination in drinking water.

Supplementary Materials: The following are available online at https: / www.mdpi.com/article / 10.3390/bios11120487/s1, Table S1: The sequence of oligonucleotides used in this work; Figure S1: Optimization of (a) the MB155 concentration using $100 \mathrm{mM}^{\circ} \mathrm{H}_{2} \mathrm{O}_{2}$, (b) the $\mathrm{H}_{2} \mathrm{O}_{2}$ concentration using $50 \mathrm{nM}$ of MB155, and (c) the reaction time for the magnetophoresis assay based on relative absorbance at $365 \mathrm{~nm}$; Figure S2: Optimization of the particle ratio for $\mathrm{Cu}^{2+}$ on-chip detection. (a) Optimization of the MB155 concentration based on a 1:1 ratio (v:v) of MMPs and PMPs. (b) Optimization of the MMP concentration by diluting the MMPs while maintaining the same ratio of MMPs to MB155, microfluidic chip fabrication, linear regression equation, limit of detection, and inverse regression. 
Author Contributions: Conceptualization, C.C. and T.-H.C.; methodology, C.C. and T.-H.C.; investigation, C.C.; data curation, C.C.; writing-original draft preparation, C.C.; writing-review and editing, T.-H.C.; supervision, T.-H.C.; project administration, T.-H.C.; funding acquisition, T.-H.C. All authors have read and agreed to the published version of the manuscript.

Funding: This research was funded by the Hong Kong Research Grant Council (11217217, 11217820, and N_CityU119/19), the Innovation and Technology Commission (ITS/098/20), and the City University of Hong Kong (9678242, 6430620, and 6000720).

Institutional Review Board Statement: Not applicable.

Informed Consent Statement: Not applicable.

Conflicts of Interest: The authors declare no conflict of interest. The funders had no role in the design of the study; in the collection, analyses, or interpretation of the data; in the writing of the manuscript, or in the decision to publish the results.

\section{References}

1. Desai, V.; Kaler, S.G. Role of copper in human neurological disorders. Am. J. Clin. Nutr. 2008, 88, 855S. [CrossRef] [PubMed]

2. Percival, S.S. Copper and immunity. Am. J. Clin. Nutr. 1998, 67, 1064S-1068S. [CrossRef] [PubMed]

3. Saari, J.T. Copper deficiency and cardiovascular disease: Role of peroxidation, glycation, and nitration. Can. J. Physiol. Pharmacol. 2000, 78, 848-855. [CrossRef] [PubMed]

4. Lentini, P.; Zanoli, L.; Granata, A.; Signorelli, S.S.; Castellino, P.; Dell'Aquila, R. Kidney and heavy metals-The role of environmental exposure (Review). Mol. Med. Rep. 2017, 15, 3413-3419. [CrossRef] [PubMed]

5. Patil, M.; Sheth, K.A.; Krishnamurthy, A.C.; Devarbhavi, H. A Review and Current Perspective on Wilson Disease. J. Clin. Exp. Hepatol. 2013, 3, 321-336. [CrossRef]

6. Montes, S.; Rivera-Mancia, S.; Diaz-Ruiz, A.; Tristan-Lopez, L.; Rios, C. Copper and Copper Proteins in Parkinson's Disease. Oxidative Med. Cell. Longev. 2014, 2014, 147251. [CrossRef]

7. Waggoner, D.J.; Bartnikas, T.B.; Gitlin, J.D. The Role of Copper in Neurodegenerative Disease. Neurobiol. Dis. 1999, 6, 221-230. [CrossRef]

8. Edition, F. Guidelines for drinking-water quality. WHO Chron. 2011, 38, 104-108.

9. Dawson, J.B.; Ellis, D.J.; Newton-John, H. Direct estimation of copper in serum and urine by atomic absorption spectroscopy. Clin. Chim. Acta 1968, 21, 33-42. [CrossRef]

10. List, G.R.; Evans, C.D.; Kwolek, W.F. Copper in edible oils: Trace amounts determined by atomic absorption spectroscopy. J. Am. Oil Chem. Soc. 1971, 48, 438-441. [CrossRef]

11. Ferreira, S.L.C.; Lemos, V.A.; Moreira, B.C.; Costa, A.C.S.; Santelli, R.E. An on-line continuous flow system for copper enrichment and determination by flame atomic absorption spectroscopy. Anal. Chim. Acta 2000, 403, 259-264. [CrossRef]

12. Townsend, A.T.; Miller, K.A.; McLean, S.; Aldous, S. The determination of copper, zinc, cadmium and lead in urine by high resolution ICP-MS. J. Anal. At. Spectrom. 1998, 13, 1213-1219. [CrossRef]

13. Hu, Q.; Yang, G.; Zhao, Y.; Yin, J. Determination of copper, nickel, cobalt, silver, lead, cadmium, and mercury ions in water by solid-phase extraction and the RP-HPLC with UV-Vis detection. Anal. Bioanal. Chem. 2003, 375, 831-835. [CrossRef] [PubMed]

14. Yin, B.-C.; Ye, B.-C.; Tan, W.; Wang, H.; Xie, C.-C. An Allosteric Dual-DNAzyme Unimolecular Probe for Colorimetric Detection of Copper(II). J. Am. Chem. Soc. 2009, 131, 14624-14625. [CrossRef]

15. Lou, T.; Chen, L.; Chen, Z.; Wang, Y.; Chen, L.; Li, J. Colorimetric Detection of Trace Copper Ions Based on Catalytic Leaching of Silver-Coated Gold Nanoparticles. ACS Appl. Mater. Interfaces 2011, 3, 4215-4220. [CrossRef]

16. Ma, Y.-R.; Niu, H.-Y.; Zhang, X.-L.; Cai, Y.-Q. Colorimetric detection of copper ions in tap water during the synthesis of silver/dopamine nanoparticles. Chem. Commun. 2011, 47, 12643-12645. [CrossRef] [PubMed]

17. Lin, M.; Cho, M.S.; Choe, W.S.; Lee, Y. Electrochemical analysis of copper ion using a Gly-Gly-His tripeptide modified poly(3thiopheneacetic acid) biosensor. Biosens. Bioelectron. 2009, 25, 28-33. [CrossRef]

18. Qing, M.; Xie, S.; Cai, W.; Tang, D.; Tang, Y.; Zhang, J.; Yuan, R. Click Chemistry Reaction-Triggered 3D DNA Walking Machine for Sensitive Electrochemical Detection of Copper Ion. Anal. Chem. 2018, 90, 11439-11445. [CrossRef]

19. Wang, J.; Zong, Q. A new turn-on fluorescent probe for the detection of copper ion in neat aqueous solution. Sens. Actuators $B$ Chem. 2015, 216, 572-577. [CrossRef]

20. Luo, M.; Di, J.; Li, L.; Tu, Y.; Yan, J. Copper ion detection with improved sensitivity through catalytic quenching of gold nanocluster fluorescence. Talanta 2018, 187, 231-236. [CrossRef]

21. Zhang, L.-P.; Xing, Y.-P.; Liu, C.; Zhou, X.-H.; Shi, H.-C. Label-free colorimetric detection of $\mathrm{Cu}^{2+}$ on the basis of Fenton reactionassisted signal amplification with unmodified gold nanoparticles as indicator. Sens. Actuators B Chem. 2015, 215, 561-567. [CrossRef]

22. Shan, Z.; Lu, M.; Wang, L.; MacDonald, B.; MacInnis, J.; Mkandawire, M.; Zhang, X.; Oakes, K.D. Chloride accelerated Fenton chemistry for the ultrasensitive and selective colorimetric detection of copper. Chem. Commun. 2016, 52, 2087-2090. [CrossRef] [PubMed] 
23. Zhao, J.; Deng, J.; Yi, Y.; Li, H.; Zhang, Y.; Yao, S. Label-free silicon quantum dots as fluorescent probe for selective and sensitive detection of copper ions. Talanta 2014, 125, 372-377. [CrossRef]

24. Wang, Y.; Wang, L.; Xue, J.; Dong, J.; Cai, J.; Hua, X.; Wang, M.; Zhang, C.; Liu, F. Signal-Amplified Lateral Flow Test Strip for Visual Detection of Cu2. PLoS ONE 2017, 12, e0169345. [CrossRef] [PubMed]

25. Clayton, C.A.; Hines, J.W.; Elkins, P.D. Detection limits with specified assurance probabilities. Anal. Chem. 1987, 59, 2506-2514. [CrossRef]

26. Lavagnini, I.; Magno, F. A statistical overview on univariate calibration, inverse regression, and detection limits: Application to gas chromatography/mass spectrometry technique. Mass Spectrom. Rev. 2007, 26, 1-18. [CrossRef] [PubMed]

27. Liu, Y.; Zhao, Y.; Zhang, Y. One-step green synthesized fluorescent carbon nanodots from bamboo leaves for copper(II) ion detection. Sens. Actuators B Chem. 2014, 196, 647-652. [CrossRef]

28. Kashima-Tanaka, M.; Tsujimoto, Y.; Yamazaki, M. Quantification of Hydroxyl Radical Generated from the $\mathrm{Fe}^{2+}-\mathrm{H}_{2} \mathrm{O}_{2}$ and $\mathrm{Cu}^{2+}-\mathrm{H}_{2} \mathrm{O}_{2}$ Reaction Systems by Electron Spin Resonance Stop and Flow Technique. Int. J. Oral-Med Sci. 2002, 1, 67-73. [CrossRef] 